\title{
Citizenship Education for Liberation in Nigeria
}

\author{
Joseph Olukayode Ogunbiyi ${ }^{1, *}$, Olukunle Saheed Oludeyi ${ }^{1}$ \\ ${ }^{1}$ Department of Sociological Studies, Tai Solarin University of Education [ ${ }^{*}$ Corresponding \\ author: ogunbiyiolukayode@yahoo.com]
}

\begin{abstract}
Across the globe, nations face a problem of low levels of civic consciousness and prevalence of harmful stereotypes like ethno-religious intolerance, prejudice and crises. In many parts of the world, these have degenerated into political crises, youth hooliganisms, prostitution, examinations malpractices, rape victimisation, terrorism and national insecurity. In the Nigerian context, these vices truncate the practical and transparent democratic governance while threatening the country's federalism and cohesion. Since the purpose of any functional education is to enlighten and liberate the beneficiaries, ensuring that they live a sustainable life while contributing meaningfully to the upkeep of their immediate community, this paper takes a look at citizenship liberation using qualitative civic education. It examines, inter alia, the aims and objectives of qualitative citizenship education and how the principles of civic education can be instilled in the citizens for liberation and peaceful co-existence. The paper further discusses how the spirit of patriotism, unity, love and oneness can be installed in the minds of Nigerians and how they can serve as a lubricant to the wheel of socio-political and economic progress of the nation through adequate citizenship education.
\end{abstract}

Keywords: Higher education for development; Sustainability; Lifelong learning.

\section{$1 \quad$ Introduction}

Liberation is a word that connotes freedom from all forms of restriction, independence and self-determination. This is in line with the etymological meaning of liberation as given by Ayeni (2012) that the word liberal is a derivative from the Latin word 'liber' which means 'free' and the plural 'liberi' which means 'free men'. The verb 'liberate' means 'to free' and the abstract noun 'liberatas' means 'freedom'. This means that there is no possible interpretation of the word 'liberal' which is more or less than 'freedom'. The overall goal of African educational system, though traditional, was to groom a 
holistic man, well-mannered and cultured as described in Yoruba concept of Omoluwabi-a complete gentleman (Sarumi, 2011). Such person is expected to be free thinker and live according to the dictate of rationality and reasoning alone rather than dictates of brainwashing and or dogma. This is because reasoning and rationality free the mind from the shackles of ignorance. A liberated mind is free of cultural superstition, ethnocentric inclination and religious dogma. The liberated man has the mind of his own and free from being gullible to anti-social cajoles courtesy of rapacious and nefarious political leaders who use people as tools for disrupting the nation's political and democratic stability, especially during elections. In the words of Ayeni (2012) individual intellectual freedom enables people to follow argument wherever it leads, and reach logical conclusions in the light of reasoning. This implies that if a man knows the difference between right and wrong, he will automatically do what is right, because to do wrong in this situation would be irrational. This is what human liberation conjures.

However, it is regrettable to state that the minds of the early peoples in Nigeria were fettered by superstition, which caused timidity in the individual who was not free to develop as his western counterpart (Ayeni, 2012). In some part of Nigeria, religious dogma were and are still constraints on individual thinking and freedom of thought, and because the constraints dominate thinking, they also determine behaviour. The individual acted out in blind obedience, not because he is guided by reason but because his sense of reasoning is clouded by excessive religious fanaticism and dogma, superstitious balderdash and ethnocentric arrogance. This is evident in the belief in and worship of terror, incessant bombing and mass killings caused by indoctrinated religious fanatics in some parts of the country.

These events of recent past have indicated that Nigeria is on the brink of losing her much cherished sense of nationhood, cultural identity and, indeed, hospitable spirit (Ogunbiyi and Soluade, 2011). The recent crises in Nigeria defied boundaries ranging from political and social to religious and sometimes appearing to have economic connotations. The recurring problems and explanations for this growing state of low sense of patriotism and nationalism emanates from the fact that Nigerian citizens are ignorant, or perhaps confused, of their duties and obligation towards the nation and sense of responsibility towards fellow citizens. The principle of living a high moral life, based on civic duties and responsibilities, in other to have a good name is always appreciated and cherished in all human societies. This is because it is a common adage that a good name is better than 'gold or silver', hence the drive for civic values and orientations (Danladi, 2011). The Nigerian National Policy on Education (2004) stresses that the philosophy of education should be geared towards equipping the learner to cultivate values of effective citizenship and civil responsibility. The Policy endorses that the philosophy behind all forms of 
instructions in schools is to be measured in terms of their roles in producing citizens with skills, competencies, moral values and reasoned judgments to effectively live, interact, interrelate and contribute positively to economic, social, political and cultural development of the Nigerian society (Okobiah, cited in Okam and Ibrahim, 2011). The philosophy begs for adequate and qualitative citizenship education.

\section{Concept and Goal of Citizenship Education}

Like most concepts in social sciences, citizenship education defies a universally acceptable definition yet many scholars have attempted conceptualising it. While others refer to it as civic education, character training, political education, behavioural modification, others construe it as human right education. Alutu and Ifedili (2012) explained the reasons why the meaning attached to the concept varies. In their words: 'since virtually all human beings possess hedonistic character, the desire to train for good citizenship is universal concept which varies from society to society depending on their specific needs and problems'[pp. 573]. Hence the nature and objectives of citizenship education in any given society is dependent on the presenting indicators in the social environment. This frantically corroborates Iyamu's (1999) definition of citizenship education as a conscious effort to inculcate in the youth, a set of values and attitude contingent on the need and problems of the society. Omare (1999) also concludes that the manifestation of citizenship education can be seen in the behavioural trait such as critical thinking, political activism, inquiry, goals and value of good citizenship. Yusuf (2006) contends that education for citizenship requires a citizen to be well informed and possess ability to gather facts, reject ethnocentrism, religious jingoism and develop positive national consciousness. This means that citizenship education will develop in individual skills, attitudes and values that will enable them to show concern for the wellbeing and dignity of others, respecting the worth of others and approaching civil decision in a rational manner. In fact, at the mention of citizenship, the individual and the state come to mind. The education of an individual concerning himself and his state that will not only socialize but emancipate and transform him for functional roles in a dynamic society is citizenship education (Anumba, 2013: 37).

However, the concept may be better described than defined. The UNESCO Recommendation concerning Education for International Understanding, Cooperation and Peace and Education relating to Human Rights and Fundamental Freedoms (1974), provide a better description of the principle of civic education for Member States as: promoting, at every stage of education, an 
active civic training which will enable every person to gain a knowledge of the method of operation and the work of public institutions, whether local, national or international; and to participate in the cultural life of the community and in public affairs. The documents state further that wherever possible, this participation should increasingly link education and action to solve problems at the local, national and international levels. Students' participation in the organisation of studies and of the educational establishment they are attending should itself be considered a factor in civic education and an important element in international education. In her description of citizenship education, Anumba (2013: 38), posit that it is the type of education that enables members of a society acquire full knowledge, not only of the state, but also of their duties and obligations to the state, their rights and expectations from the state, the necessity of total conformity with accepted ways and standards of life of the people, the need for full compliance with rules and regulations and total allegiance to the state. The summary of it all is the need for relevant education that will transform the citizens to live legally in the society and contribute meaningfully to its progress. It is this kind of socialization orientation and training that can properly be referred to as education for citizenship

The aims and objectives of citizenship education are many and varied. They include socializing children against juvenile delinquency, disrespect for elders and all sharp practices that often metamorphose into full-blown crimes such as youth hooliganisms, prostitution, examinations malpractices and gross campus misconduct. In fact there has been public outcry over unemployment against the government, while those who have gained one employment or the other demonstrate unprecedented truancy and ingratitude towards their employers. The magnitude of dishonesty, embezzlement of public funds, looting government treasuries, diverting public funds and materials to private use, bribery and corruption they practise is inexplicable (Anumba, 2013). As earlier echoed in Falade (2008), the lack of the required citizenship traits in the life of the Nigerian citizens is directly or indirectly responsible for some citizens to think of disintegration, disunity and conflicts in the country. To create a list of the purpose of citizenship education to the state, the people and the world, may be an endless pursuit.

\section{Need for Human Liberation in Nigeria and the World}

The world is relentlessly becoming a mad place to live. Since the First World War, the world ceased to be constructive because men began to refuse applying their intelligence to create international and national co-operation for peaceful and harmonious co-existence. People are now confused of what humanity really 
should stand for. Superstitions beliefs and religious dogma now obfuscate men perception of the spirit of nationhood and brotherliness. Men continue to be inhuman to men and persist in retaining the divisions of mankind into hostile groups. Russel (1977, cited in Okam \& Ibrahim, 2011) revealed the prevalence of a general collective failure in many parts of the world, on the part of men, to use the intelligence they possess for the purpose of self-preservation and advancement of humanity. According to him, many factors which have been allowed to operate vulgarly in many societal frameworks are all dragging society towards a state of social disorder. Some of these factors include, but not limited to:

1. forces of religion, sex, education, nationalism, class feeling and competition which have been allowed to operate irrationally in many parts of the world to the extent of producing in the young insanity, stupidity, readiness for homicide, economic injustice and ruthlessness;

2. forces of intolerance, hatred, pain and misfortune which have engulfed and consumed many minds such that they have lost the power of balanced judgment which is needed for an emergence from the slough in which mankind is staggering;

3. a characterization of many societies by displays of disharmonies in their political and social frameworks;

4. a menace from problems of uncertainties which not only wedge many developing countries from each other but which also militate against socioeconomic advancement; and problems of imbalance, inequality and the like which handicap many developing countries their emancipation from their colonial and apartheid history into a life which is based on equal footing with others in the world of mankind (Russel, 1977: 21-22; Okam \& Ibrahim, 2011).

What is left in the cosmos is now mad world where there is the systematic and pervasive mistreatment of individuals on the basis of their membership in various groups, which are disadvantaged by the institutionalised imbalances in social power in a particular society. A world filled with bunches of oppressors and oppressed. According to Ricky (2014), oppression includes both institutionalised or "normalised" mistreatment as well as instances of violence. It is the invalidation, denial, or the non-recognition of the complete humanness (the goodness, uniqueness, smartness and powerfulness) of those who are members of the mistreated group. This is the only way to describe the world today judging from the ubiquitous of warfare across the globe.

The Nigerian episode is a terrifying one. Since the Lugardian amalgamation of 1914, there has been an inbuilt tendency for man's intolerance and inhumanity to man. The Nigerian society is now shackled with series of enigma that posit the ending of its national cohesion and federalism. The season of 
discontent has special ramifications for a nation with unemployed millions, and the net effect has been a tragic precipitation of violent crimes: assault, burglary, extortion and kidnapping (Oludeyi, 2013). These are not unconnected to the low level of civic consciousness among the populace. Other resultant harmful stereotypes prevalent in Nigeria includes ethno-religious intolerance, prejudice and crises, political crises, youth hooliganisms, prostitution, examinations malpractices, rape, terrorist insurgencies and national insecurity. There is therefore a disturbing atmosphere of apprehensiveness among the populace (Alemika \& Chukwuma, 2006; Oludeyi, 2013) and steady rise in youth crime, nurtured in a climate of increasing national income. In the words of Oludeyi (2013), a significant number of Nigerian youths are illiterate and resultantly gullible to anti-social cajoles courtesy of rapacious and nefarious political leaders who use them as tools for disrupting the nation's political and democratic stability. Couple with the proliferation of Islamic terrorist offshoots, it is done through rigging, thuggery, and religious violence which are detrimental to national peace and security (Oludeyi, 20103). Decades of social and political turmoil have turned this strategically located African nation into an established junction for international drug smugglers. "Other highlights of Nigeria's prolific crime syndicates are economic fraud - usually in the form of innovative internet schemes; money laundering and racketeering (Osalor, 2010). The dreadful part is the mayhem of terrorist insurgency championed by Boko Haram.

The fundamental question is thus: where can the Nigerian nation and other countries of the world find succour, peace and ease of cohabiting? There is a dire and urgent need for human Liberation. Since liberation is a function of education, liberation which is both the undoing of the effects and the elimination of the causes of social anomalies can best be sought in a type of education that trains, socialises, and crystallises the learners' mind both for character building, civics rights and responsibility and the spirit of inter-vivos patriotism. A kind of education tantamount to knowledge, skills and values given to a child or groups of learners with a view to making them functional and responsible individuals capable of contributing to the socio-economic, political and religious development of the state (Osuagwu \& Ogbonnaya, 1997; Okam \& Ibrahim, 2011). This is Citizenship or Civic Education. According to Ayeni (2012) the conviction is that citizenship education aims ultimately to enable the individual to make free choices on, for example, moral issues, rather than habituate him to make correct responses without really understanding the reason for his choices. In this respect, civic education is a liberating agent for individual. The mind has to be freed from error of thinking that knowledge is based on superstition and religious dogma which is still a predominant phenomenon in Nigeria society today. It means that raising good, civic-minded 
and patriotic citizens requires an educational system that lays emphasis on civic training (Ogundare, 2002)

\section{Citizenship Education and Human Liberation}

It seems palpable that with many ills in the world today, education has long been touted as a panacea for tackling crime and criminality, socio-political and economic vices (Witte \& Tauchen, 1994; Olumade, 2009; Costelloe, 2014). According to Costelloe (2014), recent developments in mainstream education suggest that concepts such as citizenship, inclusion and democracy have become inextricably linked to changes in educational policy and practice across globe. A major discursive shift in world education debate has placed a new emphasis on the democratic and civic outcomes of the education process while introducing the concept of 'social and civic competence' (Hoskins, 2008). This has led to a prioritisation of education for citizenship and the teaching of democracy as mechanisms for the promotion and support of active citizenship (Costelloe, 2014).

According to Ricky (2014), biological/cultural/ethnic/sexual/religious/age differences between human beings are never the cause of oppression or chaos in the world today. The use of these differences to explain either why certain groups of people are oppressed (or) why certain groups of people behave oppressively or why the world is in a state of disorder, functions as a justification of oppression and violence in itself. The renowned Behavioural Psychologist, B. F. Skinner has since 1972, contends that human behaviour is the cause of most of the World's problems: crime, poverty, pollution, war, overpopulation, even health-related problems such as cancer, sexually transmitted diseases, polio, malaria, etc. For instance, the application of the physical and biological science would not solve these problems because the solution lies in another field... Better contraceptives will control population only if people use them. New methods of agriculture and medicine will not help if they are not practiced, and housing is a matter not only of buildings and cities but also of how people live. We need to make vast changes in human behaviour and it is not enough to 'use technology without a deeper understanding or liberation on human issues' or dedicate technology to man's spiritual needs or to encourage technologists to look at human problems, what we need is a technology of behaviour (quoted in Oludeyi, 2013: 15).

Contemporary events and problems in Nigeria and other parts of the world call for human liberation and character education capable of creating a civil society of unity. This can be accomplished by preparing the younger generation (both in and out of schools) with effective citizenship education and training. 
Human liberation is possible. It is possible to recover the buried memories of humans' socialization, to share stories and heal the hurts imposed by the conditioning, to act in the present in a humane and caring manner, to rebuild human connections and to change the world (Ricky, 2014). The process is essentially integrated into the curriculum imperatives of civics education; these issues and problems suggest that citizenship education has to be explored and employed to cope and embrace the pedagogical demands and dimensions entailed in seeking to liberate the citizens for civic competence and patriotism.

\section{The Liberating Values in Qualitative Citizenship Education}

It is expedient to mention that not much emphasis is placed on the teaching of civic values in the Nigeria schools. Instead of producing thinking and objective human beings, the educational system produces many fearful and uncritical citizenry that are also selfish and indifferent to public affairs (Obadan, 2004, cited in Falade, 2008).

Principles of civic education can be instilled in the citizens for liberation and peaceful co-existence. The spirit of patriotism, unity, love and oneness can be installed in the minds of Nigerians and how they can serve as lubricant to the wheel of socio-political and economic progress of the nation through adequate citizenship education. The basic liberating principles that are necessary for embedment in the core value of a qualitative citizenship education are enshrined in the Nigerian constitution. These are stated as follow:

1. Freedom of expression

2. Freedom of press and access to alternative source of information.

3. Freedom of association

4. Equality before the law and due process under the rule of law.

5. Freedom to own, buy and sell properties

Sequel to the above, there are certain values which are considered desirable and which a good citizen must possess. These traits include the development of comradeship and cooperation, as well as togetherness in the learners from their primary schools to tertiary institutions. The school curriculum should incorporate some national core values and tangible learning experience on honesty, sincerity, integrity, personality, accountability and fairness, into the lessons topic for learners. It should also include in the classroom activities, experiences on concern for others, tolerance, respect for authority, rules of law, law and order, and the right of others, respect for life and property, trustworthiness, reliability and dependability, and the benefit of hard work of citizens in the society. 


\section{Conclusion and Recommendation}

Citizenship education means more than the mere teaching of the fact about the society. It is about learning to understand and believe in democratic functions as a living and changing process in the environment. It aims to teach the citizenry some basic functional skills to be able to live a liberated and sustainable life for them to know their civic right and responsibilities and to contribute their quota to build a just, liberal and democratic society. This of course is necessary for peaceful co-existence among the citizens regardless of their religious, ethnic or biological differences. A citizen who is not trained in citizenship education is deficient in role performance, in fact ignorant of himself, of his immediate environment, the government, the state, and of course, of events beyond his state. According to Anumba (2013) retaliatory attitudes of followers, especially the youth, are the contemporary social problems plaguing Nigeria. Prolonged bad leadership by those at the helm of affairs has degenerated into insecurity in the country. The patience of the led appear to have vanished, hence the youths cash on the slightest opportunity to steal, kill, kidnap, bomb, stir up violence, and rob - just to retaliate the wrongs of the leaders. The belligerents, in the form of militants, boko haram or the like, appear to have been provoked to actions and the feeling that it is now their turn to turn the country upside down. Only concrete and effective citizenship education can purge our nation of these social vices. It is therefore safe to conclude that a country that fails to raise its citizens with qualitative citizenship education well instilled in them may be digging its grave and then raise a crop of soldiers who will crush it and bury it.

If the spirit of patriotism, unity, love and oneness can be installed in the minds of Nigerians and if they must serve as lubricant to the wheel of sociopolitical and economic progress of the nation through adequate citizenship education, the following are put forward as necessary steps that must be taken:

1. Serious emphasis need to be given to citizenship education from primary to post-secondary level of education in the country. The instructors should teach Nigerians how to manifest democratic values that promote team building for effective citizenship. This interpersonal, social interaction through the values of members will lead to shared vision, interdependency, mutual trust, strong commitment to the team, cooperation which increases the level of effort and satisfaction of members in the process of nation building.

2. Parents also should begin to rise up to their traditional duties; a situation where parents have gradually handed over the responsibility of child training to the formal system in schools is uncalled for. Charity begins at home and if parents take up their duties on their wards, it will go a long 
way in reducing youth restiveness and resultantly strengthening national peace and security (Oludeyi, 2013). In fact it should be incorporated in our laws that parents of perpetrators of evils, when caught, should also share in the punishment. According to Anumba (2013), perpetrators of these evils should be apprehended along with their parents, their names, and home addresses published in newspapers, and announced over the television and radio for consecutively six months preceding the offence. Parents should partake in the punishment arising from their children or wards' prohibited acts. It will make parents leave up to their responsibilities.

3. Citizens need to discover how to develop themselves by affirmation, visualisation, attitudes talk, positive greetings, enthusiasm and other core value in the civic education.

4. Civic education should be adopted nationally as a corrective measure to the societal disorder in the country. It should be made a compulsory lesson to all ages and all people in the country. This is because the social ills prevalent in Nigeria today cut across all ages both the leaders and the led.

5. To the foregoing more possible, media houses should be made to see citizenship education as compulsory corporate social responsibilities. In the words of Anumba (2013) broadcasting houses should make songs, jingles and slogans in condemnation of the contemporary social ills - suicide bombing, kidnapping, vandalisation, and on the other hand compose same in praise of our values, aspirations, cultures, beliefs, national symbols and national ethics.

6. Teaching and learning of civic education should cover both formal and informal system of education in Nigeria.

\section{References}

Alemika, E. E. \& Chukwuma, I. C. (2006) Criminal Victimization and Fear of Crime in Lagos Metropolis, Nigeria, Cleen Foundation Monograph Series, No. 1.

Alutu, A. N. G. and Ifedili, C. J (2012) realizing the objectives of citizenship education: the need for collaborative effort of teachers and counsellors. Interdisciplinary Journal of Contemporary Research in Business 4 (1) available online at http://journal-archieves18.webs.com/571-579.pdf

Anumba, F. N. (2013) Citizenship Education in Nigeria: For the Young, or the Old? Academic Journal of Interdisciplinary Studies Publishing, Rome-Italy Vol. 2(10) available online at http://www.mcser.org/journal/index.php/ajis/article/viewFile/1694/1698 
Ayeni, M. A (2012) Education for Liberation: Nigeria Experience. Literacy Information and Computer Education Journal, Special Issue, Volume 1 (2) available online at http://infonomicssociety.org/LICEJ/EducationforLiberationNigeriaExperience.pdf

Costelloe, A. (2014) "Learning for Liberation, Teaching for Transformation: Can Education in Prison Prepare Prisoners for Active Citizenship?" Irish Journal of Applied Social Studies: Vol.14 (1) Article 4. Available at: http://arrow.dit.ie/ijass/vol14/iss1/4

Danladi, E. N. (2011) Civic education as citizenship mission Nigerian Journal of Social Studies Vol. XIV (1) Pp. 50-61

Falade, D. A. (2008) Civic Education as a Tool for Nation Building in Nigeria. Nigerian Journal of Social Studies, Vol. XI (1) available online at http://www.sosan.org.ng/publications/N_J_S_S_PAPER_2.pdf.

Iyamu, E. O. S (1999). Citizenship education in Nigeria schools, rationale and constraints. Nigeria Journal of social educators. 2(1)35-51.

Ogunbiyi, J.O. and Soluade, Z. O. (2011) Civic Conciseness of students exposed to civic. Nigerian Journal of Social Studies Vol. XIV (2) Pp.: 135150

Ogundare, S.F. (2002) Social studies: A character education for ethnic conflict management. Nigerian Journal of Social Studies Vol. VI No 1\&2 Pp.: 178190.

Okam, C. C and Ibrahim, D. S. (2011) Exploring Emerging Myths and Realities in Citizenship Education in Nigeria: Towards Overcoming the Dilemmas of Nation-Building Journal of Educational and Social Research Vol. 1 (3) October 2011

Oludeyi, O. S. (2013) Unequal access to tertiary education; implication for national security, IOSR Journal of Humanities and Social Science Volume 9, Issue 2), PP 13 Retrieved online at http://iosrjournals.org/iosrjhss/pages/v9i2.html

Omare, O (1999). Enhancing democracy in Nigeria through citizenship education: Nigerian journal of social studies review 8 (1) 33 - 39

Osalor, P. (2010) The Solution to Combating Youth Crime in Nigeria, the Daily Eagles, access online at http://www.thedailyeagles.com/2010/10/14/thesolution-to-combating-youth-crime-in-nigeria.html

Osuagwu, C. E. and Ogbonnaya U. (1997) Colonial rule in Nigeria and its place in citizenship education, In A.M. Uzoa, G. Nwizu, and D.Njoku (eds.) Citizenship Education. Okigwe: Whytem Publishers.

Ricky S. (2014), Liberation Theory: A Working Framework. Ricky's Writings available online at http://www.unlearningracism.org/writings/lib_theory.htm

Russel, B. (1977). On Education. London: Gorge Allyn and Unwin ltd.

Yusuf, A. (2006) Citizenship Education: an Instrument for Unity and stability in Nigeria. African Journal of educational studies 4(2) Retrieved online on 
Ogunbiyi \& Oludeyi: Citizenship Education for Liberation in Nigeria

12-10-14 from http://www.musero.org.ng/publications/citizenship-educationan-instrument-for-unity-and-stability-in-nigeria.pdf. 